\title{
Collaborative Learning with Mind Mapping in the Development of Social Skills of Children
}

\author{
Özgül Polat \\ Department of Preschool Education, Atatürk Faculty of Education, Marmara University, \\ Istanbul, Turkey \\ ORCID: 0000-0001-7426-5771 \\ Türker Sezer \\ Department of Preschool Education, Faculty of Education, Bolu Abant Izzet Baysal \\ University, Bolu, Turkey \\ ORCID: 0000-0003-0898-4887 \\ Nevra Atış-Akyol ${ }^{*}$ \\ Department of Preschool Education, Faculty of Education, Cumhuriyet University, Sivas, \\ Turkey \\ ORCID: 0000-0003-4697-847X
}

Article history

Received:

10.04.2021

Received in revised form: 28.07.2021

Accepted:

13.07.2021

Key words:

Mind mapping;

Social skills;

Collaborative learning;

Preschool children
During the social process of the preschool period, the aim is to enable children to gain social skills which will help them to adapt to the classroom, and prepare them for their social life. Benefiting from cooperative teaching methods in the development of social skills supports children's interactions with each other. The carrying out of group work with new and different approaches, which incorporate collaboration in the activities, is significant for the development of the social skills and peer interactions of children. Therefore, the purpose of this research is to analyze the effect of collaborative learning with group mind mapping about social skills-related themes on the social skills performance of 60 72-month-old preschoolers. The Social Skills Assessment Scale was used as the data gathering tool in the research. A total of 35 children were included in the study as follows: 18 children in the working group and 17 children in the control group. Children carried out 5 large group mind mapping activities and 19 small group mind mapping activities by creating one mind map each week. In the study, it was concluded that mind mapping activities related to social skills have an effect on the development of the social skills of preschoolers.

\section{Introduction}

As a social being, a child expands his/her social circle through attending preschool, and learns basic social skills during this socialisation process. In fact, the preschool period is a

\footnotetext{
* Correspondency: nevrarven@gmail.com
} 
critical time in which small children gain the necessary social skills that will enable them to become socially competent individuals (Rubin, Bukowski \& Parker, 2006). Social skills are the adaptation behaviours that consist of the skills of starting and maintaining social relationships, contributing to the development of positive peer relationships, the taking into consideration of the wishes of others in the social circle, and coping with problems that may arise (Gresham, Van \& Cook, 2006; Hupp, LeBlanc, Jewell \& Warnes, 2009). In other words, social skills refer to the socially acceptable behaviours that support positive relationships, and allow the individual to interact with others by helping him/her avoid negative reactions (Gresham \& Elliot, 2008). According to Lynch and Simpson (2010), social skills are the behaviours that include skills such as empathy, communication, joining group activities, cooperation, negotiation, and problem solving which enhance the relationships of the individual with the environment in a positive way.

Nowadays, there is a greater need for individuals with high social skills who can adapt to the changes in their work and social lives (Johnston, Tobbell \& Woolley, 2011). Therefore, emphasis should be placed on the psychological, and social health of children as well as their physical growth and development (Vahedi, Farrokhi \& Farajian, 2012). In a report on social development, published in 2015 by the OECD, social health of the modern day is drawn attention to by giving suggestions to parents and teachers, with the aim of making children successful in their life, by helping them to manage the challenges, and crises they may face and to exhibit a successful performance in their work life (OECD, 2015). From the standpoint of Choi and Kim (2003), the social skills obtained in the preschool period have permanent effects on the development of children's social, emotional and academic skills. Social skills are related to academic achievement, general well-being, adaption, sanity, and social success (Carter, Briggs-Gowan \& Davis, 2004). For this reason, weak social skills may result in low academic performance, absence of friends, rejection, anxiety, and depression (Hosokawa \& Katsura, 2017; Sergin \& Giverts, 2003). It is seen in literature that various programmes which are supporting social skills applied in preschool activities, advance the social skills of children (Dereli İman, 2014; Fantuzzo, Manz, Atkins \& Meyers, 2005; Leung, 2010; Pekdoğan, 2016; Uysal \& Balkan, 2015).

Vygotsky emphasises the importance of the Zone of Proximal Development that occurs with social interactions in the ongoing development of a person throughout their life (Vygotsky, 1978). Considering the constructivist approach, in order to contribute to the development of children's social skills in the most natural conditions in the classroom environment, it is necessary to benefit from methods, techniques, and activities that will provide them with collaborative learning environments with their peers. The contribution of cooperative learning to education and training has been emphasized in a long time (Cress, Moskaliuk \& Jeong, 2016; Kafai \& Peppler, 2011; Leelawong \& Biswas, 2008; O'Donnell \& O'Kelly, 1994; Springer, Stanne \& Donovan, 1999). Collaborative learning is considered as a method in which students work in groups and cooperatively help each other to learn, in line with a common goal (Johnson \& Johnson, 2009; Sharan, 2015; Slavin, 1995). Johnson and Johnson (1992) explained the principles of collaborative learning as positive dependency, face-to-face interaction, social skills, individual evaluability, and evaluation of the group process. As can be seen, social skills, and other skills that support social skills are also included in the principles of collaborative learning. Veerman and Veldhuis-Diermanse (2001) emphasise that collaborative learning creates a suitable environment for children to reconstruct their knowledge. Because in collaborative learning, children not only have the freedom to express their own thoughts but also they must listen to their groupmates in order to solve a problem or implement a project (Neo, 2003). Based on the above information, it is thought that small 
group, and large group mind mapping activities which utilise the skills of starting, maintaining, and ending communication, listening, exchanging ideas with peers, problem solving, shared decision making, and coping with bullying, will be influential in the development of social skills among children. One of the methods in which the teacher is only a guide, and children play an active role in the teaching-learning process is the carrying out of mind mapping performed with collaborative learning. In this way, mind mapping activities will make the child's skills of understanding themselves, and others and the feeling of being a part of the group will instinctively materialize.

The beginning of mind mapping is accepted as the studies of Roger Sperry and his friends on the brain in the 1950s. This technique contributes to the cooperation of the two hemispheres of the brain, which undertake different functions, and also to multi-dimensional thinking (cited in Şeyihoğlu, Akbaş \& Kartal, 2012). Mind mapping became widespread in the 1960s after the studies of Tony Buzan, a psychologist, brain researcher, mathematician, and is now used in various fields such as education, business, and personal development (Buzan \& Buzan, 2009). Effective scientific results of mind mapping practices can be found in literature, at different levels of the education system, and various learning areas. Studies show that mind mapping contributes to fundamental academic skills such as reading, writing, science, mathematics (Inayah \& Argawati, 2019; Karolina, 2019; Khatimah \& Rachman, 2018; Mardiyah, Suhito \& Safa'atullah, 2018; Polat, Yavuz \& Tunç, 2017; Sukma \& Ria, 2018) as well as problem solving skill (Ismail, Ngah \& Umar, 2010; Sugiyanto, Masykuri \& Muzzazinah, 2018), creative thinking and teaching of science (Widiana \& Jampel, 2016), creativity (Miranti \& Wilujeng, 2017), internal motivation levels (Amin \& Hina, 2018), and memory development in learning (Irman, 2019). Numerous skills such as thinking about themes, imagination, emotions, concentration, determining possible causes, reasoning, analysis, creativity, memory, coordination, reading, writing, visualisation, planning, and application are used together with mind mapping (Wen-Cheng, Chung-Chieh \&Ying-Chien, 2010). According to Buzan (2000), mind mapping facilitates the understanding of information through interpretation. The mind maps which are like a tree with thick branches, and twigs, from a bird's eye view, simplify information with short key words (Rustler, 2012). Hence information gains an imaginary vision in the brain (Buzan, 2000). Mind mapping is used to develop a new idea or learning, recall learned information, take evocatory notes for oneself, and understand complicated information or concepts (Buzan \& Buzan, 2015).

In summary, it is essential to benefit from the innovative, and influential practices of the modern day, in order to keep up with the changing and developing world. The practices that will contribute to the development of social skills in children through group work in a natural environment, especially in the preschool period, are promoted. During mind mapping, processes such as listening, expressing one's feelings and thoughts in the proper way, evaluating different ideas, controlling oneself, struggling with peer pressure, shared decisionmaking and cooperation occur automatically. Therefore, it can be thought that mind mapping is a natural way of collaborative learning. In addition, discussion on the theme of social skills through mind maps is an approach that will raise the effectiveness of the practice. The purpose of this research is to analyse the effect of collaborative learning with group mind mapping about social skills-related themes, on the social skills of 6-year-old pre-schoolers.

\section{Method}

The research was designed using a quasi-experimental design which is one of the quantitative methods. Quasi-experimental studies aim to reveal the effect of an intervention 
applied on a group, determined randomly from within groups that already exists (Cook, Campbell \& Day, 1979). In addition, a testing model with a pre-test post-test control group was used.

\section{Working Group}

The working group of the study consisted of 35 children aged 6 years old (60-72 months) from two classes of a private preschool in Istanbul. Of the classes for aged 6 at the school, one was chosen as the experimental group while the other one was determined as the control group. The experimental, and control group contained 18 and 17 children, respectively. Detailed information about the children assigned to the experimental, and control groups were presented in Table 1.

Table 1. Descriptive statistics of the experimental, and control groups

\begin{tabular}{llllll}
\hline & & \multicolumn{2}{c}{ Experimental group } & \multicolumn{2}{c}{ Control group } \\
\cline { 3 - 6 } & & $\mathrm{f}$ & $\%$ & $\mathrm{f}$ & $\%$ \\
\hline Child Gender & Girl & 7 & 38,9 & 6 & 35,3 \\
& Boy & 11 & 61,1 & 11 & 64,7 \\
& Total & 18 & 100,0 & 17 & 100,0 \\
\hline School attendance & 1 year & 5 & 27,8 & 4 & 23,5 \\
& 2 years & 13 & 72,2 & 13 & 76,5 \\
& Total & 18 & 100,0 & 17 & 100,0 \\
\hline Mother's level of & High school & 4 & 22,2 & - & 11,8 \\
education s & Associate degree & 2 & 11,1 & 2 & 88,2 \\
& Bachelor's degree & 12 & 66,7 & 15 & 100,0 \\
\hline Father's level of & Total & 18 & 100,0 & 17 & 29,4 \\
education & High school & 4 & 22,2 & 5 & 5,9 \\
& Associate degree & - & - & 1 & 64,7 \\
& Bachelor's degree & 14 & 77,8 & 11 & 100,0 \\
\hline
\end{tabular}

According to Table 1, 7 of the children in the experimental group were girls and 11 were boys. Similarly, the control group consisted of 6 girls and 11 boys. The average age in months of the children assigned to the experimental group was 69.77 (sd:5.91), and for the control group this was 69.17 (sd:4.72). In addition, 5 of the children in the experimental group attended pre-school education for one year, 13 of them for two years. 4 of the children in the control group had attended for one year, and 13 of them for two years. Finally, most of the parents of the children in both the experimental, and control groups are undergraduates.

\section{Ethical Consideration}

Before starting the study, researchers met with school administrators and teachers about the planned research. After the meeting, teachers showed interest in mind mapping practices and all teachers ( 5 teachers) were given mind mapping training during the summer term. Then, at the beginning of the 2018-2019 school year, a meeting was held with the families of the children from the 6-year-old's classes, which were randomly determined to be the experimental, and control group. The research process was explained, and all questions from the families were answered in the meeting. A commitment was made to teachers, and families regarding the confidentiality, and use of the information to be obtained within the scope of the research, for scientific purposes only. After obtaining written consent from the families who voluntarily allowed their children to participate in the study, the research process started with verbal consent from the children. After the research was completed, mind 
mapping applications with the same themes were carried out with the children in the control group.

\section{Data Gathering Tools}

\section{Social Skills Assessment Scale -SSAS}

The scale was developed by Avcioğlu (2007) to assess the social skills of children aged 4-6. The scale, which is filled in by the class teacher according to his/her observation of each child, is a Likert-type measurement tool that consists of 62 items. There are nine subdimensions in the scale. They are as follows: interpersonal skills-IP (15 items), skills of controlling anger trigger behaviour and adapting to change-CATBAC (11 items), skills of coping with peer pressure-CPP (10 items), self-control skills-SC (4 items), verbal explanation skills-VE (7 items), skills of accepting results-AR (4 items), listening skills-LS (5 items), goal setting skills-GS (3 items) and skills of completing tasks-CT (3 items). Cronbach's alpha values of the scale varied between .78, and .98, the two half reliability coefficients between .62 and .91, and the test-retest reliability coefficients between .60, and .98 (Avcioğlu, 2007). The measurement tool is suitable for collecting data based on the opinions of teachers or parents in measuring children's social skills. In this study, the data was obtained based on the opinions of the children's teachers. The validity and reliability calculations for the measurement tool were not carried out due to the number of samples not being sufficient. The reliability coefficient between the teachers was not carried out because the experimental group was evaluated by own teacher, and the control group by owns.

\section{Data Gathering Process}

Before starting, the Mind Maps and Social Skills Activity Package (MM-SSAP) was explained to the teachers and management, for both the experimental, and control groups, and suggestions were taken. Moreover, all teachers were provided with mind mapping training to ensure equal opportunities in education. Prior to the exercise, a parents' meeting was held with families of the children in the study groups. The MM-SSAP were introduced to them, and information regarding the planned study was given.

The research data was gathered in the academic year 2018-2019. The Social Skills Assessment Scale was filled in for pre-tests, by the teachers, within a week of starting in September. Similarly, one week was given for teachers to carry out the post-tests. The activities in the MM-SSAP were performed with the experimental, and control groups two days a week, for 24 weeks. The only difference between the control group, and the experimental group was that 24 mind mapping activities (5 large group and 19 small group activities) were carried out with the experimental group.

As part of the study, the activities were performed two days a week (on Mondays, and Wednesdays) both in the experimental group, and the control group. Unlike the control group, the experimental group carried out mind mapping about the weekly theme every Friday. Thus, reinforcement of the social skill theme which was the focus point of the whole week, and interrelation of the sub-dimensions were supported with the Mind Mapping activity, which was carried out on the last day of the week. After completion of the exercises and post-tests, the control group carried out mind mapping activities for six weeks until the end of the school term in order to achieve equality for the children. 


\section{Mind Mapping Studies}

The MM-SSAP content applied to the experimental, and control groups constituted of the following 24 sub-dimensions: rules of daily life, collaboration, kindness, mediation, friendship, waiting for your turn, positive peer relationships, knowledge of one's self, expressing own feelings with positive behaviours, coping with anger, self-control, listening, completing tasks, conformity with changes, accepting results, problem solving skills, relationships with adults, goal setting, respect for diversity, emotions, empathy, solidarity, showing acceptance, and rights. The sub-dimensions were determined after research into the literature, was carried out by the researchers. Suitability, and content of the activities were assessed by 7 experts in the field to identify their scope, and validity. The necessary reorganisation was carried out based on feedback from the experts.

\section{Large Group Mind Mapping Studies}

The MM-SSAP began for the Experimental group on October 15. In the first five weeks, the mind maps themed rules of daily life, collaboration, kindness, mediation, friendship were organised as large group studies, which all children took part in. In large group activities, eight pieces of craft paper were combined to create a wide area on which to work. Mind maps were prepared with all members of the experimental group, using crayons and felt tip pens. A mind map with the theme of "Collaboration" is shown as an example in Figure 1.

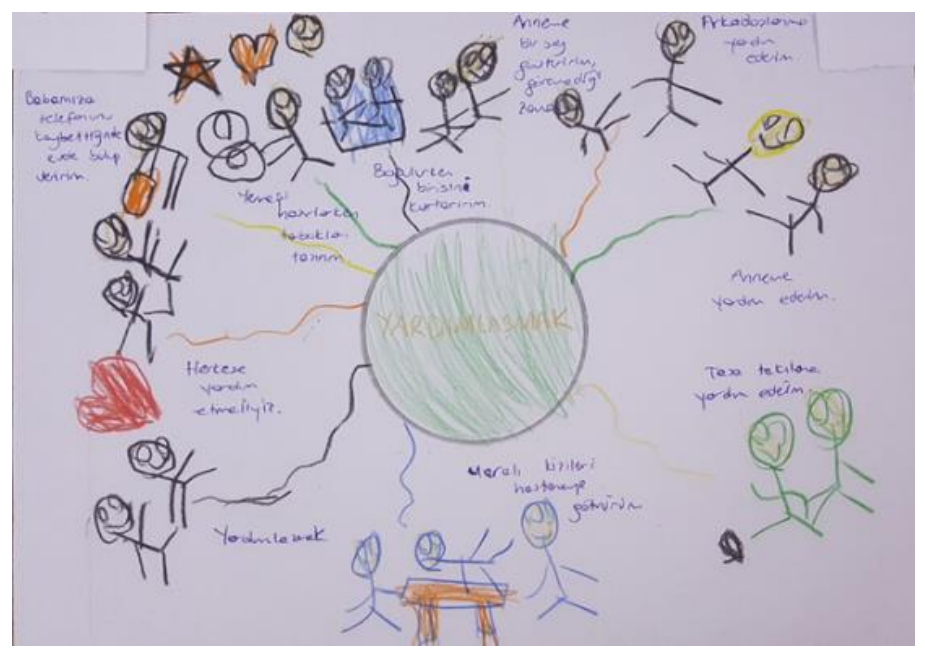

Figure 1. "Collaboration" Mind Map

The social skill theme of the relevant week was written in the centre of the sheets where the mind map was to be created. The main branches were drawn, and key words were placed accordingly. With the support of the teachers, the researchers created a comfortable environment, accompanied by music, and gave the children information about the theme, and the key words. Children lay down and illustrated their ideas on the main branches, and subbranches they wanted, using coloured crayons. No intervention took place during this process. The researchers, and teacher wrote what the children drew below the pictures after listening to what they had to say about them. In addition, the researchers, and the teacher encouraged them to exchange ideas with their friends, and perform peer learning. The children were guided to establish the relationship networks between their ideas by associating their pictures with the main branch, main theme, and sub-branches. The children who expressed their thoughts on a main branch, and sub-branches switched to another main branch. 


\section{Small Group Mind Mapping Studies}

From week 6, the MM-SSAP were performed by combining 2 pieces of Kraft paper and small group studies were conducted with 4-5 students. Similarly, peer learning in small groups was encouraged. In addition, 19 activities were carried out based on the following subthemes: waiting for your turn, positive peer relationships, knowledge of oneself, expressing own feelings with positive behaviours, coping with anger, self-control, listening, completing tasks, conformity with changes, accepting results, problem solving skills, relationships with adults, goal setting, respect for diversity, emotions, empathy, solidarity, showing acceptance and rights. A mind map with the theme of "Emotions" is shown as an example in Figure 2

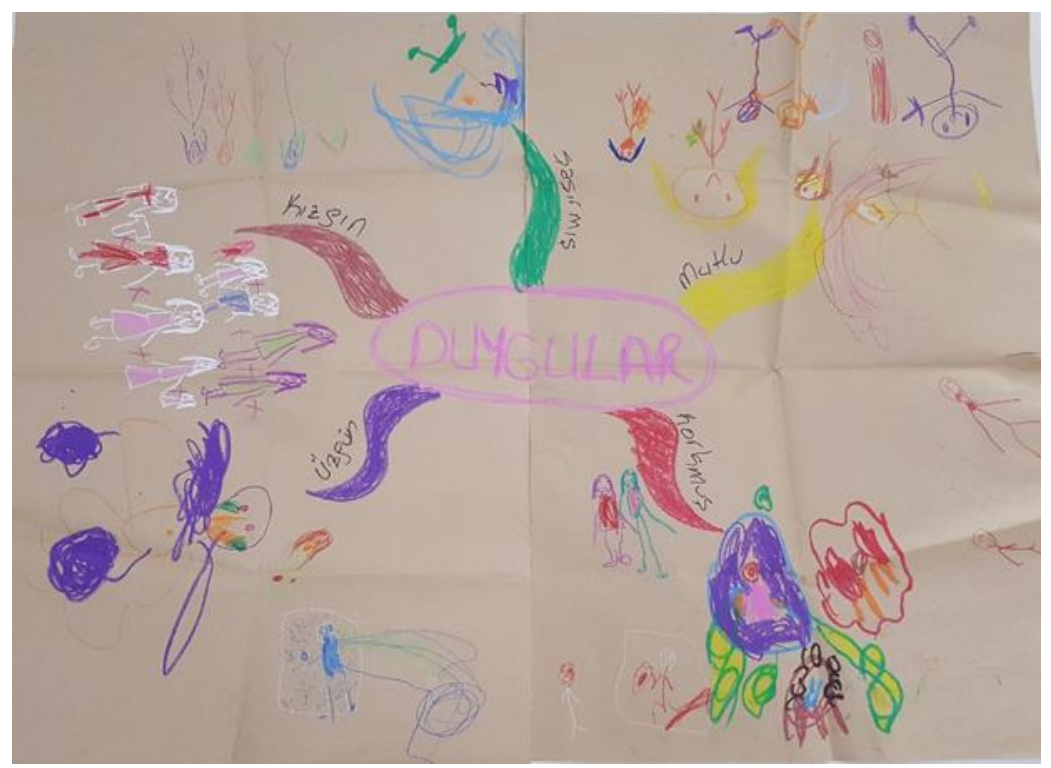

Figure 2. "Emotions" Mind Map

\section{Data Analysis}

In data analysis, data sets were generated by carrying out the necessary coding. Data distribution was examined with the Shapiro-Wilk test (McKillup, 2012) using an appropriate statistics package programme. It was found that the CATBAC, VE and total pre-test scores of the control group and the CATBAC post-test scores of the experimental group had a normal distribution ( $p>.05)$, and the distribution of both the pre-test, and post-test scores for the other sub-dimensions was not normal $(\mathrm{p}<.05)$. Furthermore, non-parametric Mann Whitney test, and Wilcoxon Signed Ranks test were utilised, considering causes such as the number of children in each of the experimental, and control groups was less than 30 .

\section{Findings}

Analyses were carried out regarding the SSAS scores of the children in the experimental and control groups, and the findings are presented below.

Table 2. Pre-test results of the experimental, and control groups

\begin{tabular}{llllllll}
\hline Sub-dimensions & Group & $\mathbf{N}$ & $\begin{array}{l}\text { Mean } \\
\text { Rank }\end{array}$ & $\begin{array}{l}\text { Sum of } \\
\text { Ranks }\end{array}$ & $\mathbf{U}$ & $\mathbf{z}$ & $\boldsymbol{p}$ \\
\hline IS & Experimental & 18 & 20.97 & 377.50 & 99.500 & -1.771 & .077 \\
& Control & 17 & 14.85 & 252.50 & & & \\
& Total & 35 & & & & & \\
\hline CATBAC & Experimental & 18 & 18.36 & 330.50 & 146.500 & -.216 & .832
\end{tabular}




\begin{tabular}{|c|c|c|c|c|c|c|c|}
\hline & Control & 17 & 17.62 & 299.50 & & & \\
\hline CPP & $\begin{array}{l}\text { Total } \\
\text { Experimental }\end{array}$ & $\frac{35}{18}$ & 16.00 & 288.00 & 117.000 & -1.194 & .245 \\
\hline & Control & 17 & 20.12 & 342.00 & & & \\
\hline & Total & 35 & & & & & \\
\hline $\mathrm{SC}$ & Experimental & 18 & 18.58 & 334.50 & 142.500 & -.352 & .732 \\
\hline & Control & 17 & 17.38 & 295.50 & & & \\
\hline & Total & 35 & & & & & \\
\hline VE & Experimental & 18 & 19.22 & 346.00 & 131.000 & -.731 & .483 \\
\hline & Control & 17 & 16.71 & 284.00 & & & \\
\hline & Total & 35 & & & & & \\
\hline $\mathrm{AR}$ & Experimental & 18 & 17.61 & 317.00 & 146.000 & -.234 & .832 \\
\hline & Control & 17 & 18.41 & 313.00 & & & \\
\hline & Total & 35 & & & & & \\
\hline LS & Experimental & 18 & 20.36 & 366.50 & 110.500 & -1.430 & .163 \\
\hline & Control & 17 & 15.50 & 263.50 & & & \\
\hline & Total & 35 & & & & & \\
\hline GS & Experimental & 18 & 18.47 & 332.50 & 144.500 & -.289 & .782 \\
\hline & Control & 17 & 17.50 & 297.50 & & & \\
\hline & Total & 35 & & & & & \\
\hline CT & Experimental & 18 & 19.36 & 348.50 & 128.500 & -.827 & 424 \\
\hline & Control & 17 & 16.56 & 281.50 & & & \\
\hline & Total & 35 & & & & & \\
\hline Total Score & Experimental & 18 & 19.94 & 359.00 & 118.000 & -1.156 & .258 \\
\hline & Control & 17 & 15.94 & 271.00 & & & \\
\hline & Total & 35 & & & & & \\
\hline
\end{tabular}

IS: Interpersonal skills, CATBAC: Skills of controlling anger trigger behaviours, and adapting to change, CPP: Skills of coping with peer pressure, SC: Self-control skills, VE: Verbal explanation skills, AR: Skills of accepting results, LS: listening skills, GS: Goal setting skills, CT: Skills of completing tasks ${ }^{*} p<.05,{ }^{* *} p<.01,{ }^{* * *} p<.001$

In Table 2, according to the results of the Mann Whitney U test performed for the SSAS pretest scores for the experimental, and control groups, it was determined that there were no significant difference between the SSAS sub-dimensions, and total scores of both groups ( $\mathrm{p}>$ $.05)$

Table 3. Pre-test, and post-test results of the experimental group

\begin{tabular}{|c|c|c|c|c|c|c|}
\hline Sub-dimensions & & $\mathbf{N}$ & $\begin{array}{l}\text { Mean } \\
\text { Rank } \\
\end{array}$ & $\begin{array}{l}\text { Sum of } \\
\text { Ranks }\end{array}$ & $\mathbf{z}$ & $\mathbf{p}$ \\
\hline \multirow{4}{*}{ IS post-test and pre-test } & Negative ranks & 0 & .00 & .00 & -3.730 & $.000^{* * * *}$ \\
\hline & Positive ranks & 18 & 9.50 & 171.00 & & \\
\hline & Equal & 0 & & & & \\
\hline & Total & 18 & & & & \\
\hline \multirow{4}{*}{$\begin{array}{l}\text { CATBAC post-test and pre- } \\
\text { test }\end{array}$} & Negative ranks & 0 & .00 & .00 & -3.727 & $.000^{* * * *}$ \\
\hline & Positive ranks & 18 & 9.50 & 171.00 & & \\
\hline & Equal & 0 & & & & \\
\hline & Total & 18 & & & & \\
\hline \multirow{4}{*}{ CPP post-test and pre-test } & Negative ranks & 0 & .00 & .00 & -3.729 & $.000^{* * * *}$ \\
\hline & Positive ranks & 18 & 9.50 & 171.00 & & \\
\hline & Equal & 0 & & & & \\
\hline & Total & 18 & & & & \\
\hline \multirow{4}{*}{ SC post-test and pre-test } & Negative ranks & 0 & .00 & .00 & -3.742 & $.000^{* * * * *}$ \\
\hline & Positive ranks & 18 & 9.50 & 171.00 & & \\
\hline & Equal & 0 & & & & \\
\hline & Total & 18 & & & & \\
\hline \multirow{2}{*}{ VE post-test and pre-test } & Negative ranks & 0 & .00 & .00 & -3.741 & $.000^{* * * *}$ \\
\hline & Positive ranks & 18 & 9.50 & 171.00 & & \\
\hline
\end{tabular}




\begin{tabular}{|c|c|c|c|c|c|c|}
\hline & $\begin{array}{l}\text { Equal } \\
\text { Total }\end{array}$ & $\begin{array}{l}0 \\
18\end{array}$ & & & & \\
\hline \multirow{4}{*}{ AR post-test and pre-test } & Negative ranks & 0 & .00 & .00 & 3.779 & $.000^{* * * *}$ \\
\hline & Positive ranks & 18 & 9.50 & 171.00 & & \\
\hline & Equal & 0 & & & & \\
\hline & Total & 18 & & & & \\
\hline \multirow{4}{*}{ LS post-test and pre-test } & Negative ranks & 0 & .00 & .00 & -3.736 & $.000^{* * * *}$ \\
\hline & Positive ranks & 18 & 9.50 & 171.00 & & \\
\hline & Equal & 0 & & & & \\
\hline & Total & 18 & & & & \\
\hline \multirow{4}{*}{ GS post-test and pre-test } & Negative ranks & 0 & .00 & .00 & -3.780 & $.000^{* * * *}$ \\
\hline & Positive ranks & 18 & 9.50 & 171.00 & & \\
\hline & Equal & 0 & & & & \\
\hline & Total & 18 & & & & \\
\hline \multirow{4}{*}{ CT post-test and pre-test } & Negative ranks & 0 & .00 & .00 & -3.746 & $.000^{* * * *}$ \\
\hline & Positive ranks & 18 & 9.50 & 171.00 & & \\
\hline & Equal & 0 & & & & \\
\hline & Total & 18 & & & & \\
\hline \multirow{4}{*}{$\begin{array}{l}\text { Total Score post-test and pre- } \\
\text { test }\end{array}$} & Negative ranks & 0 & .00 & .00 & -3.724 & $.000^{* * * *}$ \\
\hline & Positive ranks & 18 & 9.50 & 171.00 & & \\
\hline & Equal & 0 & & & & \\
\hline & Total & 18 & & & & \\
\hline
\end{tabular}

IS: Interpersonal skills, CATBAC: Skills of controlling anger trigger behaviours, and adapting to change, CPP: Skills of coping with peer pressure, SC: Self-control skills, VE: Verbal explanation skills, AR: Skills of accepting results, LS: listening skills, GS: Goal setting skills, CT: Skills of completing tasks ${ }^{*} p<.05,{ }^{* *} p<.01,{ }^{* * *} p<.001$

Results of the Wilcoxon Signed Ranks test performed between the SSAS pre-test, and posttest scores of the experimental group are given in Table 3. Interpersonal skills $(\mathrm{z}=-3.730$, $\mathrm{p}<.05, \mathrm{r}=.62)$, skills of controlling anger trigger behaviours, and adapting to change $(\mathrm{z}=-$ $3.727, \mathrm{p}<.05, \mathrm{r}=.62)$, skills of coping with peer pressure $(\mathrm{z}=-3.729, \mathrm{p}<.05, \mathrm{r}=.62)$, self-control skills $(\mathrm{z}=-3.742, \mathrm{p}<.05, \mathrm{r}=.62)$, verbal explanation skills $(\mathrm{z}=-3.741, \mathrm{p}<.05, \mathrm{r}=.62)$, skills of accepting results $(\mathrm{z}=-3.779, \mathrm{p}<.05, \mathrm{r}=.63)$, listening skills $(\mathrm{z}=-3.736, \mathrm{p}<.05, \mathrm{r}=.62)$, goal setting skills $(\mathrm{z}=-3.780, \mathrm{p}<.05, \mathrm{r}=.63)$, skills of completing tasks $(\mathrm{z}=-3.746, \mathrm{p}<.05, \mathrm{r}=.62)$, and total score $(\mathrm{z}=-3.724, \mathrm{p}<.05, \mathrm{r}=.62)$ show that the pre-test scores of the experimental group are significantly higher than its post-test scores.

The " $r$ " values indicate the effect of the exercise with respect to SSAS sub-dimensions, and total score. The " $r$ " values reached here are above all the sub-dimensions and total scores of the exercise by at least .60. Such effects represent a high impact (Cohen, 1988; Field \& Hole, 2003; Thalheimer \& Cook, 2002). In other words, the exercise performed with the experimental group, considerably affected the social skills of the children.

Table 4. Pre-test and post-test results of the control group

\begin{tabular}{|c|c|c|c|c|c|c|}
\hline Sub-dimension & & $\mathbf{N}$ & $\begin{array}{l}\text { Mean } \\
\text { Rank }\end{array}$ & $\begin{array}{l}\text { Sum of } \\
\text { Ranks }\end{array}$ & $\mathbf{Z}$ & $\mathbf{p}$ \\
\hline \multirow{4}{*}{ IS post-test and pre-test } & Negative ranks & 0 & .00 & .00 & -3.632 & $.000^{* * * *}$ \\
\hline & Positive ranks & 17 & 9.00 & 153.00 & & \\
\hline & Equal & 0 & & & & \\
\hline & Total & 17 & & & & \\
\hline \multirow{4}{*}{$\begin{array}{l}\text { CATBAC post-test and pre- } \\
\text { test }\end{array}$} & Negative ranks & 0 & .00 & .00 & -3.633 & $.000^{* * * *}$ \\
\hline & Positive ranks & 17 & 9.00 & 153.00 & & \\
\hline & Equal & 0 & & & & \\
\hline & Total & 17 & & & & \\
\hline \multirow{2}{*}{ CPP post-test and pre-test } & Negative ranks & 0 & .00 & .00 & -3.625 & $.000^{* * *}$ \\
\hline & Positive ranks & 17 & 9.00 & 153.00 & & \\
\hline
\end{tabular}




\begin{tabular}{|c|c|c|c|c|c|c|}
\hline & Equal & 0 & & & & \\
\hline & Total & 17 & & & & \\
\hline & Negative ranks & 0 & .00 & .00 & -3.662 & $.000^{* * * *}$ \\
\hline & Positive ranks & 17 & 9.00 & 153.00 & & \\
\hline $\mathrm{SC}$ post-test and pre-test & Equal & 0 & & & & \\
\hline & Total & 17 & & & & \\
\hline & Negative ranks & 0 & .00 & .00 & -3.628 & $.000^{* * * *}$ \\
\hline & Positive ranks & 17 & 9.00 & 153.00 & & \\
\hline VE post-test and pre-test & Equal & 0 & & & & \\
\hline & Total & 17 & & & & \\
\hline & Negative ranks & 0 & .00 & .00 & -3.632 & $.000^{* * *}$ \\
\hline & Positive ranks & 17 & 9.00 & 153.00 & & \\
\hline AR post-test and pre-test & Equal & 0 & & & & \\
\hline & Total & 17 & & & & \\
\hline & Negative ranks & 0 & .00 & .00 & -3.420 & $.001^{* * *}$ \\
\hline I $\mathrm{S}$ poct tect and pre tect & Positive ranks & 15 & 8.00 & 120.00 & & \\
\hline LS post-test and pre-test & Equal & 2 & & & & \\
\hline & Total & 17 & & & & \\
\hline & Negative ranks & 0 & .00 & .00 & -3.646 & $.000^{* * * *}$ \\
\hline CS nost_toct and pre-tect & Positive ranks & 17 & 9.00 & 153.00 & & \\
\hline GS post-test and pre-test & Equal & 0 & & & & \\
\hline & Total & 17 & & & & \\
\hline & Negative ranks & 0 & .00 & .00 & -3.637 & $.000^{* * *}$ \\
\hline & Positive ranks & 17 & 9.00 & 153.00 & & \\
\hline CT post-test and pre-test & Equal & 0 & & & & \\
\hline & Total & 17 & & & & \\
\hline & Negative ranks & 0 & .00 & .00 & -3.623 & $.000^{* * * *}$ \\
\hline Total Score post-test and pre- & Positive ranks & 17 & 9.00 & 153.00 & & \\
\hline & Equal & 0 & & & & \\
\hline & Total & 17 & & & & \\
\hline
\end{tabular}

IS: Interpersonal skills, CATBAC: Skills of controlling anger trigger behaviours and adapting to change, CPP: Skills of coping with peer pressure, SC: Self-control skills, VE: Verbal explanation skills, AR: Skills of accepting results, LS: listening skills, GS: Goal setting skills, CT: Skills of completing tasks

${ }^{*} p<.05,{ }^{* *} p<.01,{ }^{* * *} p<.001$

The results of the Wilcoxon Signed Ranks test performed between the SSAS pre-test and post-test scores of the control group are shown in Table 4. Interpersonal skills $(\mathrm{z}=-3.632$, $\mathrm{p}<.05, \mathrm{r}=.60)$, skills of controlling anger trigger behaviours and adapting to changes $(\mathrm{z}=-$ $3.633, \mathrm{p}<.05, \mathrm{r}=.62)$, skills of coping with peer pressure $(\mathrm{z}=-3.625, \mathrm{p}<.05, \mathrm{r}=.62)$, self-control skills $(\mathrm{z}=-3.662, \mathrm{p}<.05, \mathrm{r}=.63)$, verbal explanation skills $(\mathrm{z}=-3.628, \mathrm{p}<.05, \mathrm{r}=.62)$, skills of accepting results $(\mathrm{z}=-3.632, \mathrm{p}<.05, \mathrm{r}=.62)$, listening skills $(\mathrm{z}=-3.420, \mathrm{p}<.05, \mathrm{r}=.58)$, goal setting skills $(\mathrm{z}=-3.646, \mathrm{p}<.05, \mathrm{r}=.62)$, skills of completing tasks $(\mathrm{z}=-3.637, \mathrm{p}<.05, \mathrm{r}=.62)$, and social skills total $(\mathrm{z}=-3.623, \mathrm{p}<.05, \mathrm{r}=.62)$ showing that the pre-test scores of the control group are significantly higher than its post-test scores.

The "r" values show the effect of the Social Skills Activity Package, with respect to the SSAS sub-dimensions and total score. The " $r$ " values calculated here are over .50 in all subdimensions and total scores of the exercise. This effect represents a high impact (Cohen, 1988; Field \& Hole, 2003; Thalheimer \& Cook, 2002). Namely, the programme offered to the control group, considerably affected the social skills of the children. 
Table 5. Post-test results of the experimental, and control groups

\begin{tabular}{|c|c|c|c|c|c|c|c|}
\hline Sub-dimensions & Group & $\mathbf{N}$ & $\begin{array}{l}\text { Mean } \\
\text { Rank }\end{array}$ & $\begin{array}{l}\text { Sum of } \\
\text { Ranks }\end{array}$ & $\mathbf{U}$ & $\mathbf{z}$ & $p$ \\
\hline \multirow[t]{3}{*}{$\overline{I S}$} & Experimental & 18 & 24.97 & 449.50 & 27.500 & -4.296 & $.000^{* * * *}$ \\
\hline & Control & 17 & 10.62 & 180.50 & & & \\
\hline & Total & 35 & & & & & \\
\hline \multirow[t]{3}{*}{ CATBAC } & Experimental & 18 & 23.31 & 419.50 & 57.500 & -3.186 & $.001^{\text {*** }}$ \\
\hline & Control & 17 & 12.38 & 210.50 & & & \\
\hline & Total & 35 & & & & & \\
\hline \multirow[t]{3}{*}{$\overline{\mathrm{CPP}}$} & Experimental & 18 & 22.61 & 407.00 & 70.000 & -2.787 & $.005^{* *}$ \\
\hline & Control & 17 & 13.12 & 223.00 & & & \\
\hline & Total & 35 & & & & & \\
\hline \multirow[t]{3}{*}{$\mathrm{SC}$} & Experimental & 18 & 22.64 & 407.50 & 69.500 & -2.787 & $.005^{* *}$ \\
\hline & Control & 17 & 13.09 & 222.50 & & & \\
\hline & Total & 35 & & & & & \\
\hline \multirow[t]{3}{*}{$\overline{\mathrm{VE}}$} & Experimental & 18 & 23.47 & 422.50 & 54.500 & -3.333 & $.001^{* * *}$ \\
\hline & Control & 17 & 12.21 & 207.50 & & & \\
\hline & Total & 35 & & & & & \\
\hline \multirow[t]{3}{*}{$\overline{\mathrm{AR}}$} & Experimental & 18 & 19.89 & 358.00 & 119.000 & -1.175 & .240 \\
\hline & Control & 17 & 16.00 & 272.00 & & & \\
\hline & Total & 35 & & & & & \\
\hline \multirow[t]{3}{*}{$\overline{\mathrm{LS}}$} & Experimental & 18 & 21.17 & 381.00 & 96.000 & -2.178 & $.029^{*}$ \\
\hline & Control & 17 & 14.65 & 249.00 & & & \\
\hline & Total & 35 & & & & & \\
\hline \multirow[t]{3}{*}{ GS } & Experimental & 18 & 23.69 & 426.50 & 50.500 & -3.541 & $.000^{* * * * *}$ \\
\hline & Control & 17 & 11.97 & 203.50 & & & \\
\hline & Total & 35 & & & & & \\
\hline \multirow[t]{3}{*}{$\overline{\mathrm{CT}}$} & Experimental & 18 & 22.00 & 396.00 & 81.000 & -2.633 & $.008^{* *}$ \\
\hline & Control & 17 & 13.76 & 234.00 & & & \\
\hline & Total & 35 & & & & & \\
\hline \multirow[t]{3}{*}{ Total Score } & Experimental & 18 & 26.31 & 473.50 & 3.500 & -4.937 & $.000^{* * * * *}$ \\
\hline & Control & 17 & 9.21 & 156.50 & & & \\
\hline & Total & 35 & & & & & \\
\hline
\end{tabular}

IS: Interpersonal skills, CATBAC: Skills of controlling anger trigger behaviours and adapting to change, CPP: Skills of coping with peer pressure, SC: Self-control skills, VE: Verbal explanation skills, AR: Skills of accepting results, LS: listening skills, GS: Goal setting skills, CT: Skills of completing tasks ${ }^{*} p<.05,{ }^{* *} p<.01,{ }^{* * *} p<.001$

Table 5 contains the results of the Mann Whitney U test carried out for the SSAS post-test scores of the experimental, and control groups. It revealed that the interpersonal skill scores $(\mathrm{U}=27.500, \mathrm{p}<.05, \mathrm{r}=.72)$, scores of the skills of controlling anger trigger behaviours and adapting to changes $(\mathrm{U}=57.500, \mathrm{p}<.05, \mathrm{r}=.53)$, scores of the skills of coping with peer pressure $(\mathrm{U}=70.000, \mathrm{p}<.05, \mathrm{r}=.47)$, self-control skill scores $(\mathrm{U}=69.500, \mathrm{p}<.05, \mathrm{r}=.47)$, verbal explanation skill scores $(\mathrm{U}=54.500, \mathrm{p}<.05, \mathrm{r}=.56)$, listening skill scores $(\mathrm{U}=96.000, \mathrm{p}<.05$, $\mathrm{r}=.36)$, goal setting skill scores $(\mathrm{U}=50.500, \mathrm{p}<.05, \mathrm{r}=.60)$, scores of the skills of completing tasks $(\mathrm{U}=81.000, \mathrm{p}<.05, \mathrm{r}=.44)$, and social skills total scores $(\mathrm{U}=3.500, \mathrm{p}<.05, \mathrm{r}=.83)$ differed significantly, and based on the mean ranks, the significant differences are in favour of the experimental group. In contrast to the previous findings, it was discovered that there is no significant difference in the scores of the skills of accepting results ( $U=119.000, p>.05)$ between the experimental, and control groups.

When assessing the difference in the size of the effect we see that the greatest effect is on the social skills total, and interpersonal skills (Cohen, 1988; Field \& Hole, 2003; Thalheimer \& Cook, 2002). In other words, the mind map technique applied with the children in the experimental group remarkably influenced their social skills. 


\section{Results and Discussion}

In the study, the Social Skills Activity Package was applied to both the experimental and control groups but mind mapping was only carried out with the children in the experimental group following the activity packages. When looking at the post-test scores of the experimental, and control groups, it was seen that the mind map technique carried out with the children in the experimental group, remarkably influenced their social skills. When assessing the difference in the size of the effect, we see that the greatest effect is on the social skills total, and the interpersonal skills (Cohen, 1988; Field \&Hole, 2003; Thalheimer \& Cook, 2002). It can be understood from this, that mind mapping develops interpersonal skills with peers among children. Any other research that analyses the effect of mind mapping on the development of social skills was not found in literature. However, when the content of the study, and the nature of mind mapping are examined, it is predicted that mind mapping will contribute to the development of social skills. During the study, children who performed small, and large group mind mapping activities with the theme of social skills, thought about the themes with their peers and reached a consensus after listening to their ideas. Sometimes, they insisted on their own ideas but finally obtained a collective idea. During these processes, children tried to establish a relationship between their ideas by brainstorming, and showed their decisions in their mind maps, through cooperation. It is one of the reasons that children's social skills were supported by mind mapping. In a study by Tavares et. al. (2015), it is stated that social relationships, and social skills are connected to the hippocampus of the brain, and such connections may form the navigation of the brain with the mapping method (Tavares et. al., 2015). This study supports the research finding as well. According to Buzan and Buzan 2009, mind mapping applications are considered to be a technique that supports the cooperation of the brain's hemispheres.

In the relevant line of literature, there are studies that demonstrate the effect of mind mapping on the development of several skills which can be associated with social skills. For example, the impact of mind mapping on understanding and vocabulary skills was revealed in a study which examined the effect of mind mapping on both skills during the preschool period. (Koster, Wilt, Kruistum \& van der Veen, 2017). When the results of this study were evaluated in respect of social skills, it was thought that the listening skills of children and their skills of understanding the things they have heard, as well as the skills of self-expression with proper words can be supported with mind mapping, so mind mapping will indirectly, and positively affect social skills. Kokotovich (2008) indicates that mind mapping is important for the analysis of problems and the development of thinking skills. Being able to analyse the problems of daily life with a broad perspective is important for the development of social skills. Sundararajan, Adesope and Cavagnetto (2018) found that the collaborative mind mapping practices they did with preschool children were effective in the development of critical thinking skills. While performing mind mapping, children cooperate with their peers by expressing their own ideas, thereby improving their social skills by taking individual, and group responsibilities. Furthermore, similar to the acquisition of all skills, motivation is also extremely necessary for social skills because it promotes the ability to focus on tasks, and thereby think about the topic and share ideas with peers. It was indicated by various studies that the motivation of the implementer is raised with mind mapping (Amin \& Hina, 2018; Jones, Ruff, Snyder, Petrich \& Koonce, 2012; Pratami, Puspita \& Hadining, 2017). Liu, Zhao, $\mathrm{Ma}$ and Bo (2014) revealed in their meta-analysis study that mind mapping exercises promote teaching, and learning. Namely, mind mapping can be used as a learning tool with which active participation is achieved (Edwards \& Cooper, 2010). With mind mapping, which contributes to the harmonious functioning of the two hemispheres of the brain, learning 
becomes permanent by associating old information with new information, and it is stated that what children know, and learn remains in memory for a long time, especially when verbal expressions are visualized (Buzan \& Buzan 2009; Şeyihoğlu, Akbaş \& Kartal, 2012). In summary, the above studies showed the positive effect of mind mapping on the development of the skills of listening, understanding the things heard, self-expression, problem analysis, developing thinking skills, motivation, teaching, and learning. Thus, it can be said that such skills contribute to the advancement of social skills.

Vygotsky believes that the lifetime development process is based on interaction, and in fact, the learning achieved through social interactions leads to cognitive development. He advocates that children learn skills under adult guidance or with peer cooperation. Later, they reach the new real knowledge or the new development level by internalising such learning. According to Vygotsky, this development level, that contains the skills which a child cannot perform automatically, and can achieve only with adult or peer support, is called the Zone of Proximal Development-ZPD (Vygotsky, 1978). It is necessary to support the socialisation processes, and social skills of children in the preschool period, to support their adaptation to cooperation, and teamwork, is important both in terms of the personal development of the children, and for them to be able to keep up with social life and work life in the future. According to Zahedi and Heaton (2016), mind mapping with group cooperation is as important as the subject of mind mapping that is sometimes done. Because mind maps contribute to the discussion of the team members' thoughts, priorities, and allow teams to determine the direction of the project more easily by developing a common understanding. It is stated that most of the students emphasise the importance of this process (Zahedi \& Heaton, 2016). Therefore, cooperative mind mapping supports the social relations of children, and contributes to the development of joint decisions, and joint learning. The social skills gained at preschool pave the way for the skills that will help children in their academic lives (Lin, Lawrence \& Gorrell, 2003). Polat and Atış-Akyol (2016) concluded in their study that primary school readiness of children who can establish good relationships with peers is higher. Similarly, Yüksel, Küçükoğlu and Ünsal (2013) stated in their study that social skills are the predictor for primary school readiness in children. They asserted that education which aims to support social skills during the preschool period influences social skill levels of the primary school children positively, and in this way, children adapt to the primary school environment more easily. These studies are important for highlighting the significance of supporting peer-to-peer learning. Providing an interactive classroom environment which will promote peer-to-peer learning is important for children to develop their social skills. According to the findings obtained from a large-scale study about the general state of preschool education in Turkey, teachers frequently include collaboration activities in their syllabus (Polat, 2019). Children's skills of rearranging their thoughts will increase if they work in collaboration by using the cognitive processes such as planning, monitoring, and evaluation through mind mapping. As such, the process can be enriched through the use of mind mapping during the preschool period, and can create new, interesting, and effective learning for the children, and practitioners. In addition, it is thought that mind mapping supports children's knowledge and skill acquisition.

\section{Limitations}

The study is limited to the study group, which is one of the limitations of experimental research. All the teachers participating in the study have undergraduate education, and their professional experience is over five years. In addition, they regularly keep reports on the development of children every year within the scope of the national programme such as 
"development observation form", "development report" (MEB, 2013). For this reason, it is not thought that there is a limitation in the evaluation process caused by teachers. Children in the experimental, and control groups are homogeneous groups in terms of mother and father education level, and child factors (age, school attendance and gender), environmental factors, and the effect of external factors is similar for both groups. One of the major limitations of this study is the inability to perform follow-up testing due to time constraints. Another is that data on children's social skills were collected from a secondary source, through the teachers.

\section{Suggestions}

As is understood from the study results, it is seen that mind mapping supports the social skills of children. For this reason, it is important to use mind mapping regularly in the preschool period, and to give teachers training. It is recommended to increase the number of academic studies on this subject. In new experimental studies to be done on mind mapping, follow-up tests are recommended. In addition, in new experimental studies to be carried out with mind mapping, it is recommended to work with different age groups in the pre-school period or with children who develop differently.

The effects of the activities applied using the mind mapping method on other developmental areas can be investigated.

\section{References}

Amin, M., \& Hina, Q. A. (2018). Effect of mind mapping technique on student intrinsic motivation at higher education level. Journal of Research, 12 (2), 296-313.

Avcıoğlu, H. (2007). Sosyal becerileri değerlendirme ölçeğinin geçerlik ve güvenirlik çalışması (4-6 yaş) [The validity and reliability study of the Social Skills Assessment Scale (Age 4-6)]. Abant Izzet Baysal University Journal of Faculty of Education, 7 (2), 93-103.

Buzan, T. (2000). The mind map book, Penguin Books. New York: The Buzan Organisation Ltd.

Buzan, T., \& Buzan, B. (2009). The mind map book: Unlock your creativity, boost your memory, change your life. Harlow, England: Pearson

Buzan, T., \& Buzan, B. (2015) Zihin haritaları [Mind maps] (Çev. G. Tercanl1). 4. Baskı. İstanbul: Alfa.

Carter, A. S., Briggs-Gowan, M. J., \& Davis, N. O. (2004). Assessment of young children's social-emotional development and psychopathology: Recent advances and recommendations for practice. Journal of Child Psychology and Psychiatry, 45 (1), 109-134. https://doi.org/10.1046/j.0021-9630.2003.00316.x

Choi, D. H., \& Kim, J. (2003). Practicing social skills training for young children with low peer acceptance: A cognitive-social learning model. Early Childhood Education Journal. 31 (1), 41-46. https://doi.org/10.1023/A:1025184718597

Cohen, J. C. (1988). Statistical power analysis for the behavioral sciences (2nd Ed.). Hillsdale, NJ: Lawrence Earlbaum Associates.

Cook, T. D., Campbell, D. T., \& Day, A. (1979). Quasi-experimentation: Design \& analysis issues for field settings (Vol. 351). Boston: Houghton Mifflin.

Cress, U., Moskaliuk, J., \& Jeong, H. (Eds.). (2016). Mass collaboration and education. Cham, Switzerland: Springer International.

Dereli İman, E. (2014). Değerler eğitimi programının 5-6 yaş çocukların sosyal gelişimine etkisi: Sosyal beceri, psiko-sosyal gelişim ve sosyal problem çözme becerisi [The effect of the values education programme on 5-6 year-old children's social 
development: Social skills, psycho-social development and social problem solving skills]. Educational Administration: Theory and Practice, 14 (1), 249-268.

Edwards, S., \& Cooper, N. (2010). Mind mapping as a teaching resource. The clinical teacher, 7 (4), 236-239.

Fantuzzo, J., Manz, P., Atkins, M., \& Meyers, R. (2005). Peer-mediated treatment of socially withdrawn maltreated preschool children: Cultivating natural community resources. Journal of Clinical Child and Adolescent Psychology, 34, 320-325. https://doi.org/10.1207/s15374424jccp3402_11

Field, A., \& Hole, G. (2003). How to design and report experiments. London, SAGE Publications Ltd.

Gresham, F. M., \& Elliott, S. N. (2008). Social skills improvement system rating scales. Minneapolis, MN: Pearson Assessments.

Gresham, F. M., Van, M. B., \& Cook, C. R. (2006). Social skills training for teaching replacement behaviors: Remediating acquisition deficits in at-risk students. Behavioral Disorders, 31 (4), 363-377. doi:10.1177/019874290603100402.

Hosokawa, R., \& Katsura, T. (2017). Marital relationship, parenting practices, and social skills development in preschool children. Child. Adolesc Psychiatry Ment. Health, 11(1), 1-8. https://doi.org/10.1186/s13034-016-0139-y

Hupp, S. D. A., LeBlanc, M., Jewell, J. D., \& Warnes, E. (2009). History and overview. J. L. Matson (Ed.) In Social behavior and skills in children (pp. 1-21). New York: Springer.

Inayah, R., \& Argawati, N. O. (2019). Nurturing students'writing narrative interest through mind mapping and cooperative integrated reading and writing. Indonesian EFL Journal, 5 (2), 121-130. https://doi.org/10.25134/iefljv5i2.1781.

Irman, I. (2019). The effectiveness of mind mapping techniques in counseling of enhancement ability memory students in learning. Ta'dib, 22 (2), 131-140.

Ismail, M. N., Ngah, N. A., \& Umar, I. N. (2010). The effects of mind mapping with cooperative learning on programming performance, problem solving skill and metacognitive knowledge among computer science students. Journal of Educational Computing Research, 42 (1), 35-61. https://doi.org/10.2190/EC.42.1.b

Johnson, D. W., \& Johnson, R. T. (2009). An educational psychology success story: Social interdependence theory and cooperative learning. Journal of Educational Researcher, 38 (5), 365-379. https://doi.org/10.3102/0013189X09339057

Johnson, D., \& Johnson, R. (1992). Advanced cooperative learning. Edina, MN: Interaction Book Company.

Johnston, J., Tobbell, C., \& Woolley, R. (2011). Personal, social and emotional development. New York, NY: Continuum International Publishing.

Jones, B. D., Ruff, C., Snyder, J. D., Petrich, B., \& Koonce, C. (2012). The effects of mind mapping activities on students' motivation. International Journal fort he Scholarship of Teaching and Learning, 6 (1), 1-21.

Kafai, Y. B., \& Peppler, K. A. (2011). Beyond small groups: New opportunities for research in Computer-Supported Collective Learning. In H. Spada, G. Stahl, N. Miyake, \& N. Law (Eds.), Connecting Computer Supported Collaborative Learning: CSCL2011 Conference Proceeding Volume I-Long papers (pp. 17-24). Hong Kong, China: International Society of the Learning Sciences.

Karolina, K. (2019). The effectiveness of mind mapping technique in enhancing students'reading achievement. Lingua Didaktika: Jurnal Bahasa dan Pembelajaran Bahasa, 13 (1), 60-65. http://dx.doi.org/10.24036/ld.v13i1.36633

Khatimah, K., \& Rachman, D. (2018). Mind mapping vs Semantic mapping: Which technique gives efl learners more benefits in reading comprehension? JEES (Journal of English Educators Society), 3 (2), 165-176. https://doi.org/10.21070/jees.v3i2.1498 
Kokotovich, V. (2008). Problem analysis and thinking tools: An empirical study of nonhierarchical mind mapping. Design Studies, 29 (1), 49-69. https://doi.org/10.1016/j.destud.2007.09.001

Koster, M., van der Wilt, F., van Kruistum, C., \& van der Veen, C. (2017). The effect of mind mapping on listening comprehension and vocabulary in early childhood education. In European Association for Research on Learning and Instruction.

Leelawong, K., \& Biswas, G. (2008). Designing learning by teaching agents: The Betty's brain system. International Journal of Artificial Intelligence in Education, 18, 181208.

Leung, C. (2010). An experimental study of eduplay and social competence among preschool students in Hong Kong. Early Child Development and Care, 181 (4), 535-548. https://doi.org/10.1080/03004431003611487

Lin, H. L., Lawrence, F. R., \& Gorrell, J. (2003). Kindergarten teachers' views of children's readiness for school. Early Childhood Research Quarterly, 18 (2), 225-237. https://doi.org/10.1016/S0885-2006(03)00028-0

Liu, Y.,Zhao, G., Ma, G., \& Bo, Y. (2014). The effect of mind mapping on teaching and learning: a meta-analysis. Standard Journal of Educationand Essay, 2 (1), 17-31.

Lynch, S. A., \& Simpson, C. G. (2010). Social skills: Laying the foundation for success. Dimensions of Early Childhood, 38 (2), 3-11.

Mardiyah, I., Suhito, S., \& Safa'atullah, M. F. (2018). Analysis of mathematical reasoning ability of junior high school students of grade VII viewed from cognitive style on problem based learning with mind mapping. Unnes Journal of Mathematics Education, 7 (2), 122-128. https://doi.org/10.15294/ujme.v7i2.24883

McKillup, S. (2012). Statistics explained: An introductory guide for life scientists (Second edition). United States: Cambridge University Press.

MEB. (2013). Preschool education curricula. TR Ministry of National Education, Ankara.

Miranti, M. G., \& Wilujeng, B. Y. (2017, September). Creative thinking skills enhancement using mind mapping. In 1st International Conference on Social, Applied Science and Technology in Home Economics. Atlantis Press.

Neo, M. (2003). Developing a collaborative learning environment using a web based design. Journal of Computer Assisted Learning. 19, 462-473. https://doi.org/10.1046/j.02664909.2003.00050.x

O'Donnell, A. M., \& O'Kelly, J. (1994). Learning from peers: Beyond the rhetoric of positive results. Educational Psychology Review, 6, 321-349.

OECD. (2015). Skills for social progress: The power of social and emotional skills, oecd skills studies. OECD Publishing. ISBN 978-92-64-22615-9.

Pekdoğan, S. (2016). Hikaye temelli sosyal beceri eğitim programının 5-6 yaş çocukların sosyal becerilerinin gelişimine etkisinin incelenmesi [Investigation of the effect of Story-Based Social Skills Training Program on the social skill development of 5-6 year-old children]. Education ve Science, 41 (183), 305-318. http://dx.doi.org/10.15390/EB.2016.4618

Polat, Ö. (2019). Türkiye'de okul öncesi eğitimin genel durumu [General state of preschool education in Turkey]. Ankara: Testfen.

Polat, Ö., \& Atış-Akyol, N. (2016). Analyzing the relationship between school readiness and peer relations of five-year-old children. International Journal on New Trends in Education and Their Implications, 7(4), 29-39.

Polat, Ö., Yavuz, E. A., \& Tunc, A. B. O. (2017). The Effect of Using Mind Maps on the Development of Maths and Science Skills. Cypriot Journal of Educational Sciences, $12(5), 32-45$. 
Pratami, D., Puspita, I. A., \& Hadining, A. F. (2017). The Effect of "MindMap" knowledge codification implementation and motivation to individual achievement. Advanced Science Letters, 23 (5), 4110-4114. https://doi.org/10.1166/as1.2017.8255

Rubin, K. H., Bukowski, W. M., \& Parker, J. G. (2006). Peer interactions, relationships, and groups. In N. Eisenberg (Ed.), Handbook of child psychology, Vol. 3 (pp. 571-645). Hoboken, NJ: Wiley.

Rustler, F. (2012). Mind mapping for dummies. John Wiley \& Sons.

Sergin, C., \& Giverts, M. (2003). Methods of social skills training and developments. In J. O. Grene ve B. R. Burleson (Eds.), Handbook of communication and social interaction skills (pp.135-178). NJ: Lawrence Erlbaum Associates.

Şeyihoğlu, A., Akbaş, Y., \& Kartal, A. (2012) Uygulama örnekleri ile coğrafya eğitiminde kavram ve zihin haritaları [Concept, and mind maps in geography education with application examples], Ankara: Pegem Academy Publications.

Sharan, Y. (2015). Meaningful learning in the cooperative classroom. Education 3-13, 43 (1), 83-94. https://doi.org/10.1080/03004279.2015.961723

Slavin, R. E. (1995). Cooperative learning: Theory, research, and practice. Boston: Allyn and Bacon.

Springer, L., Stanne, M. E., \& Donovan, S. S. (1999). Effects of small-group learning on undergraduates in science, mathematics, engineering, and technology: A metaanalysis. Review of Educational Research, 69 (1), 21-51.

Sugiyanto, F. N., Masykuri, M., \& Muzzazinah, M. (2018). Feasibility of respiratory system module based on creative problem solving learning model with mind mapping to empower problem solving skills. EDUSAINS, 10 (2), 275-281. https://doi.org/10.15408/es.v10i2.8054

Sukma, D. E., \& Ria, G. (2018). The use of mind mapping picture to improve students'writing skill of descriptive text at grade VIII of SMP s Johan Sentosa. $A L$ ISHLAH: Jurnal Pendidikan, 10 (2), 188-197.

Sundararajan, N., Adesope, O., \& Cavagnetto, A. (2018). The process of collaborative concept mapping in kindergarten and the effect on critical thinking skills. Journal of STEM Education, 19 (1), 5-13.

Tavares, R. M., Mendelsohn, A., Grossman, Y., Williams, C. H., Shapiro, M., Trope, Y., \& Schiller, D. (2015). A map for social navigation in the human brain. Neuron, 87 (1), 231-243.

Thalheimer, W., \& Cook, S. (2002). How to calculate effect sizes from published research: A simplified methodology. Work-Learning Research, 1, 1-9.

Uysal, A. \& Balkan, İ. K. (2015). Sosyal beceri eğitimi alan ve almayan okul öncesi çocukların, sosyal beceri ve benlik kavramı düzeyleri açısından karşılaştırılması [Comparison of preschool children's social skill levels and self concept who received and who did not received social skills training]. Studies in Psychology, 35 (1), 27-56.

Vahedi, S., Farrokhi, F., \& Farajian, F. (2012). Competence and behavior problems in preschool children. Iran. J. Psychiatry 7, 126-134.

Veerman, A., \& Veldhuis-Diermanse, E. (2001). Collaborative learning through computermediated communication in academic education. In Euro CSCL 2001 (pp. 625-632). Maastricht: McLuhan institute, University of Maastricht. Vygotsky. L. S. (1978). Mind in society: The development of higher psychological processes. Cambridge, MA: Harvard University Press.

Wen-Cheng, W., Chung-Chieh, L., \& Ying-Chien, C. (2010). A brief review on developing creative thinking in young children by mind mapping. International Business Research, 3 (3), 233-238. 
Widiana, I. W., \& Jampel, I. N. (2016). Improving students' creative thinking and achievement through the implementation of multiple intelligence approach with mind mapping. International Journal of Evaluation and Research in Education, 5 (3), 246254.

Yüksel, M., Küçükoğlu, E., \& Ünsal, F. Ö. (2013). Analysing the school readiness of preschoolers from the aspect of the social skills when they start primary school. International Journal on New Trends in Education and Their Implications. 4 (2), 98112.

Zahedi, M., \& Heaton, L. (2016). Mind mapping as a tool, as a process, as a problem/solution space. In DS 83: Proceedings of the 18th International Conference on Engineering and Product Design Education (E\&PDE16), Design Education: Collaboration and Cross-Disciplinarity, Aalborg, Denmark, 8th-9th September 2016 (pp. 166-171). 